\title{
Conquer the Declining of Urban Food Security: A Concatenation of Participation \& Social Capital upon Economic Empowerment study in Klang Valley, Malaysia
}

Nur Shuhamin Nazuri, Nobaya Ahmad, Mohd Roslan Rosnon, Siti Shazwani Ahmad Suhaimi, Razif Sazali

To Link this Article: http://dx.doi.org/10.6007/IJARBSS/v11-i12/11864

DOI:10.6007/IJARBSS/v11-i12/11864

Received: 04 October 2021, Revised: 05 November 2021, Accepted: 28 November 2021

Published Online: 16 December 2021

In-Text Citation: (Nazuri et al., 2021)

To Cite this Article: Nazuri, N. S., Ahmad, N., Rosnon, M. R., Suhaimi, S. S. A., \& Sazali, R. (2021). Conquer the Declining of Urban Food Security: A Concatenation of Participation \& Social Capital upon Economic Empowerment study in Klang Valley, Malaysia. International Journal of Academic Research in Business and Social Sciences, 11(12), 1085-1096.

\section{Copyright: (c) 2021 The Author(s)}

Published by Human Resource Management Academic Research Society (www.hrmars.com) This article is published under the Creative Commons Attribution (CC BY 4.0) license. Anyone may reproduce, distribute, translate and create derivative works of this article (for both commercial and non0-commercial purposes), subject to full attribution to the original publication and authors. The full terms of this license may be seen at: http://creativecommons.org/licences/by/4.0/legalcode

Vol. 11, No. 12, 2021, Pg. $1085-1096$

Full Terms \& Conditions of access and use can be found at http://hrmars.com/index.php/pages/detail/publication-ethics 


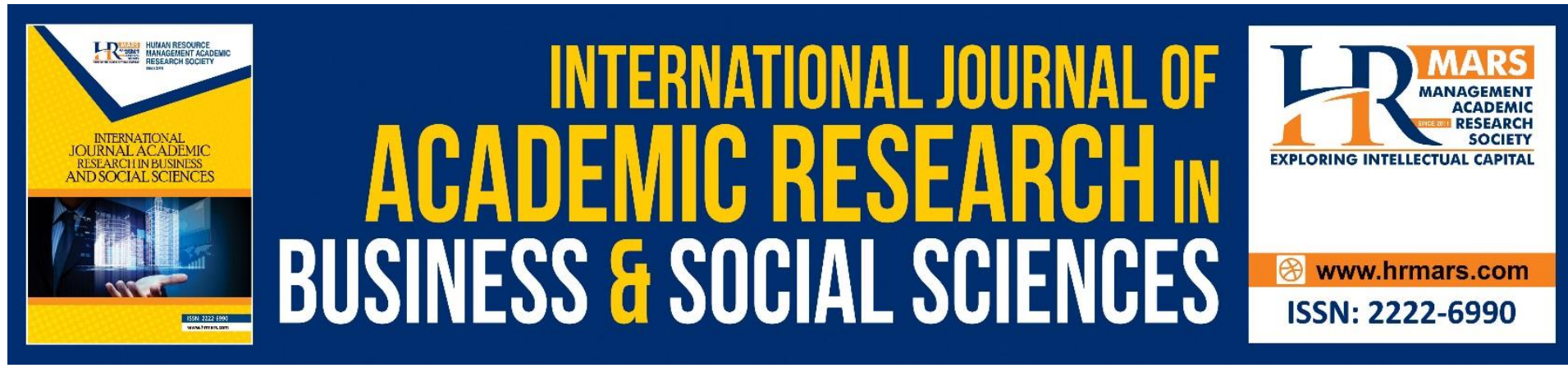

\title{
Conquer the Declining of Urban Food Security: A Concatenation of Participation \& Social Capital upon Economic Empowerment study in Klang Valley, Malaysia
}

\author{
Nur Shuhamin Nazuria, Nobaya Ahmad ${ }^{a}$, Mohd Roslan \\ Rosnon $^{a}$, Siti Shazwani Ahmad Suhaimia ${ }^{a}$, Razif Sazalib \\ aFaculty of Human Ecology, Universiti Putra Malaysia, Serdang, Malaysia Universiti Putra \\ Malaysia, Serdang, Malaysia, bFaculty of Sports Science and Recreation, Universiti Teknologi \\ MARA, Seremban Campus, Negeri Sembilan, Malaysia \\ Corresponding Author: nobaya@upm.edu.my
}

\begin{abstract}
Urban agriculture (UA) is one of the Malaysian government's initiatives to overcome food security issues by providing food or related services within or on the edges of urban areas. In relation to that, one of the ideas is to empower the local community in developing the social capital of the nation through the government UA programs. However, there is an existing gap on the effectiveness of the impact of UA towards the respective community. Hence, through this study, it will discover the factors that affect the empowerment of UA program's participants. Total of 212 respondents between the ages of 21 years old to 60 years and above from the Klang Valley region (vicinal town of Selangor and Kuala Lumpur States of Malaysia) have participated in this study. The data were collected through the survey in qualitative study and interpreted using the SPSS software. Through the analysis, it is found that the respondents have high levels in the planning program for bonding social capital, bridging social capital, and economic empowerment. In addition, the factors of linking social capital, planning, and evaluation in a program are among the significant predictors of empowerment of UA program's participants. Also, the finding of this study adds to the new point of view in complexities associated with UA among urban communities. On the other hand, it is beneficial for policy makers to utilize extension officers' role in Malaysia as a tool to increase the participation of Klang Valley urban communities to partake in Urban Agriculture project. It is recommended for more specific courses and involvement of many stakeholders to enhance urban communities' awareness and acceptance towards Urban Agriculture. Positively, this study suggests a new direction for getting more urban dwellers to be involved in innovative cultivation activities, and in the end, it would make agriculture attractive and maintain its sustainability.
\end{abstract}

Keywords: Social Capital, Participation, Economic Empowerment, Urban Agriculture, Food Security, Poverty Eradication 


\section{Introduction}

As the world population increased, urbanization trends were moving in parallel, whereby more people were expected to live in cities, leading to an increase in the number of people living in urban areas (Cohen, 2015). According to Sun et al (2020), 80\% of the large cities in the world experienced population growth. Consequently, more than half a million people were also expected to live in urban areas (United Nations, 2014). In fact, in Asia Countries. The level of urbanization in Asia now approximates at $50 \%$ population in total (United Nations, 2018). Specifically, talking about the country of Malaysia has achieved rapid economic growth and now becoming one of the most urbanized developing countries in the world. As the urbanization rate was accelerated, Malaysia had been listed as the third-highest country (76\%) in South East Asia with a high urban population in 2019 (World Urbanization Prospects, 2019). The migration of people from rural to urban areas resulted in resource depletion, higher food costs, food insecurity, high cost of living, jobless citizens, and urban poverty (Siwar et al., 2016). The rapid urbanization process is pulling poverty into urban communities as urban dwellers are typically net food buyers and depend mostly on cash income to access food (Islam and Siwar, 2012). As a result, the increasing number of populations in the city created a big demand for basic needs like quality food (Poulsen et al., 2018).

Due to these reasons, food was a big concern for urban people since food was basically imported from other countries as the city dwellers must spend half of their income to get quality food (Poulsen et al., 2018). Therefore, urban agriculture (UA) can be looked at as an effective way to secure and access food (Corrigan, 2011). Urban Agriculture (UA) is described as a new way of practices of producing, processing, and marketing food and agricultural products in cities and their surroundings by applying intensive production methods, natural resources, and waste to produce food such as vegetables, fruits, fish, herbs, and cattle (Horst et al., 2017). It is a practical approach among urban populations to produce their own food in urban areas to reduce the burden of the cost of living. UA's initiative has garnered global interest due to its potential for providing green space and assisting in the cultivation of fresh food sources, as well as for fostering communal solidarity, spreading agricultural knowledge, and consequently generating revenue. UA also has been recognized in resolving community concerns on food sufficiency and subsistence in urban and suburban areas in most countries, especially in developing countries.

Moving towards this plan of urban farming, Malaysia has been recognized as one of the developing countries that are practicing UA as a major strategy towards improving food security. Reflecting on the history, the concept of UA has existed in Malaysia since 1974 through the Green Book Plan and the Green Earth Campaign in 2006. Then, it was recommenced in 2014 governed by the Department of Agriculture (DOA) which involved residents in urban areas joint forces by various departments and agencies at the State and Federal levels. It is certainly seen as one of the efforts of the local community through the conservation of abandoned areas or spaces by utilizing the space for agricultural activities using recycled materials and on saving money (Zaidi et al., 2019). The objective of the government program enforced is to encourage locals to grow and produce their own food to meet daily needs and reduce the cost of living, increase the side income of urban communities through surplus production of agricultural products, support government efforts in ensuring food quality and security, foster moderation and interest in the importance of agriculture as a direct contributor to the well-being of the urban community (DOA, 2019). Since its introduction, the participation of UA participants has been extremely stimulating where a 
total of 63,130 urban and suburban residents have participated in this program at 2,715 locations nationwide.

The UA program is not a new concept in Malaysia. Therefore, this study is important as the UA program has been practiced for so long where it has been culturally embedded across neighborhoods in urban areas. However, to this date, lack of research conducted on social capital and participation of UA program's participants. Generally, UA program is a simple concept and practice that emphasizes the importance of civic engagement and community organizing with a coordinated approach (Cohen and Reynold, 2015). It should be underlined that food security in urban communities cannot be expected to address all of the evils associated with the current food system. By engaging community members as partners in attempts to tackle urban food security issues, there is a possibility for communities to be empowered. Therefore, it is important utilizing social capital and participation to empower the UA program's participants where in the future it could generally precede evaluation of its impact and consequently ensuring the sustainability of the program. In short, the general objective of this paper is to explore which factors influenced the economic empowerment of the UA program's participants. The detailed objective is shown below:

- To describe the socio-demographic characteristics of the UA program's participants.

- To determine the level of participation, social capital, and economic empowerment of the UA program's participants.

- To predict to what extent social capital and participation dimensions influenced the economic empowerment of UA program's participants.

\section{Literature Review}

Social capital also is the primary notion that has been introduced a long time ago in a community development program (Tirmizi, 2005). Social capital can be defined as social networks of individuals or groups and their willingness to support each other (Putnam, 2000). Social capital also has generally recognized positive consequences on economic development in recent literature (Abdul-Hakim et al., 2010). In outlining the, there are three distinct social capital dimensions, namely bonding, bridging and linking. Bonding social capital is described as people in a homogenous group or community and expressed a strong ties relationship among each other. The elements of trust, understanding, and solidarity among individuals of the group are factors that enriched the development of the group to reach their full potential (Putnam, 1993). Next, bonding social capital is defined as a strong, dense relationship of the individual and the others, who are close to each other such as family members, neighbors, close friends, and members in a small group (Gittell \& Vidal, 1998; Putnam, 2013; Wakefield \& Blake, 2005; Woolcock \& Narayan, 2000). However, the benefits of bonding social capital were only limited and effective to the small group as it is only included in the local community while excludes those outside the community (Putnam, 1993).

Another element is the bridging social capital concept that is crucial to community development as it is defined as a causal factor to determine the well-being of different communities. Generally, bridging social capital is described as social relationships of exchange, often associations between people with the same interest goals but contrasting social identity (Pelling \& High, 2005). According to Burt (2001), bridging social capital refers to how diverse groups collaborate together to establish their goal by providing information and connecting more social interaction with others outside of the organization. The Bridging elements empower different groups to share and exchange ideas, knowledge, and skills between groups in order to develop their capabilities in programs or activities. Researchers 
have found that bridging relationships brings benefits such as new information and connections to the individuals related and also to the larger community (Kavanaugh et al., 2005; Putnam, 2000). However, the relationship tended to be weaker, owing to the realities of space-time and therefore less frequent of interaction (Claridge, 2018).

Emphasizing social bridging, the third type of social capital is crucial to capture the power dynamics of vertical associations and it is also referred to as linking social capital. Additionally, linking social capital symbolize the relations between individuals and groups in different social strata in a hierarchy whereby power, social status, and wealth were accessed by different groups in order to indicate the relations between individuals and groups in the ladder or power-based relationships (Woolcock, 2001). Linking social capital specified not just as a relationship between individual or group and the stakeholder such as institutions, government agencies, and NGOs but also focus on the merit of a program which can be achieved if the government and several private agencies work jointly with the purpose for development of the program (Bebbington \& Carroll, 2000).

Pertaining to this study, relying on these three elements of social capital (bonding, bridging, and linking) are perceived important indicators of a community's empowerment. A close relationship among UA community members is a vital factor that encourages the community to get involved actively in this government program. The development of relationships among community members leads to an increased number of willing participants to participate in this program. As the past studies justified, social capital contributes to communities' unity, engagement, and empowerment of UA program's participants.

Asnarulkhadi \& Aref (2011) examined community participation through two lenses: participation as a means and as a goal. As a means, community members are not directly involved in decision-making, which is determined by the government in order to accomplish predetermined goals that may or may not align with their wishes (Asnarulkhadi \& Aref, 2011). As a goal, participation entails direct involvement of community members in decision-making, planning, and development activity implementation processes that are tailored to their needs and desires. This is also viewed as a process that assists community members in developing their capacity, or their capacity to recognize and improve their own potential.

According to Lyndon et al (2011), there are three elements involved in the participation process focusing on UA programs namely planning, implementation and evaluation. Planning is the first method in participatory approach and acts as a developing strategy to accomplish the objective of the program. In a planned program, planners should consider how the program operates, the schedule, the time frame of the program as well as the size of the targeted group. Basically, only two to three persons were involved at the beginning of the activity which consisting from the group of local activists or community leaders that demonstrated their leadership in coordinating, mobilizing, encouraging, and influencing their friends to participate in the activity (Laverack \& Labonte, 2000). Moreover, Laverack \& Labonte (2000) study agreed that the use of strategic and accurate participatory planning approaches could enhance the project plan. Precisely, the initial stage of project planning would be able to improve stakeholder engagement, build relationships, and motivate community members.

Secondly, implementation appeared as the second stage in the program's participation. Implementation served as a core element of the project in which the strategic goal could not be achieved without the operation (Riwalnu, 2011). In furtherance of strengthening the implementation of the program, the community should create, employ and 
incorporate the community structure to follow the approach that leads to notable achievements (Bryson, 2018). At the last stage, the participants undergo the evaluation process. The purpose of this stage was to determine how to measure the success of the program and community outcomes. Evaluation is an integral component of the relationship between participation and performance (Fielden et al., 2011). In this study, the evaluation's objective was to evaluate whether the objective of the program had been achieved and benefited the participants.

\section{Methods}

The data were gathered by applying the multistage random sampling method. A total of 212 respondents from the UA program's participants around the Klang Valley region (vicinal town of Selangor and Kuala Lumpur States of Malaysia) was selected as the respondents. The self-administered questionnaire survey was employed in the data collection process.

The questionnaire consists of four sections using 5 points Likert scale as the response rate. The study is based on quantitative method approach and the instrumentation design has broadly covered the area as below:

i. Socio-demographic of participants 5 items.

ii. Participation of UA program's participants adapted from Riwalnu (2014) (5 items addressing planning process, 6 items addressing implementation process, and 4 items for evaluation process).

iii. Social capital of UA program's participants was adapted from Ibrahim (2016) consisting of bonding (5 items), bridging (5 items), and linking (4 items).

iv. Empowerment of UA program's participants with 6 items of economic empowerment adapted from Ndaeji (2014) and Rezai et al. (2014).

Descriptive statistics such as frequency, percentage, mean and standard deviation were used to fulfill the determined objective. In answering the extent social capital and participation dimensions influenced economic empowerment of UA program's participants were used. Ensuring the validity of the questionnaire, the reliability test was conducted as shown in Table 1. From the test, it showed high reliability of instruments measures on participation, social capital, and empowerment which stipulated high values of Cronbach alpha ranging from 0.786 to 0.991 . This ensured that the items employed in this study possess high internal consistency, where each set of items are closely related as a group.

Table 1: Reliability test

\begin{tabular}{lcc}
\hline \multicolumn{1}{c}{ Variables } & No. Items & Cronbach Alpha, $\boldsymbol{\alpha}$ \\
\hline Participation & & \\
Planning & 5 & 0.786 \\
Implementation & 6 & 0.937 \\
Evaluation & 4 & 0.991 \\
Social capital & & \\
Bonding & 5 & 0.945 \\
Bridging & 5 & 0.883 \\
Linking & 4 & 0.854 \\
Economic Empowerment & 9 & 0.925 \\
\hline
\end{tabular}




\section{Results \& Discussion \\ Demographic Respondents}

The demographic profile of the selected sample populations included age, gender, marital status, level of education and number of households, working sectors, type of participation, and duration of participation. According to Table 2, the majority of respondents were in the age group of 41-60 years old (64.6\%) while the minority of them were between the ages $21-40$ years old (10.8\%). The respondents' age ranged between 21 to 74 years old. The age's mean score is 53.76, showing that most of them are in the old age range. A large majority of the respondents were male $(62.7 \%)$ and a few (37.3\%) were female. In terms of marital status, it was clarified that $94.3 \%$ were married couples that participated in the program, followed by $4.2 \%$ were single and $1.4 \%$ were widower. As for educational level, the result noticed that $62.3 \%$ of respondents were secondary school/vocational leavers. Apart from this, $32.5 \%$ of respondents hold diplomas/degrees from colleges and universities, while the rest of respondents (5.2\%) were from primary schools.

Table 2: Socio-demographic characteristics and background of UA activities $(n=212)$

\begin{tabular}{lcc}
\hline \multicolumn{1}{c}{ Variables } & Frequency & Percent \\
\hline Age Groups & & \\
$21-40$ & 23 & $10.8 \%$ \\
$41-60$ & 137 & $64.6 \%$ \\
61 and above & 52 & $24.5 \%$ \\
Gender & & \\
Male & 133 & $62.7 \%$ \\
Female & 79 & $37.3 \%$ \\
Marital Status & & \\
Single Married & 9 & $4.2 \%$ \\
Widow/widower & 200 & $94.3 \%$ \\
Marital Status & 3 & $1.4 \%$ \\
Level of Education & & \\
Primary school & 11 & $5.2 \%$ \\
Secondary school/ Vocational & 132 & $62.3 \%$ \\
College/ University & 69 & $32.5 \%$ \\
\hline
\end{tabular}

As portrayed in Table 3, it can be concluded that the majority of respondents have high levels in the planning program (42\%) but low in implementation and evaluation in the program (39.20\%) and (42.90\%). In terms of social capital, bonding and bridging social capital among participants recorded a slightly high percentage which is $(53.30 \%)$ and $(40.10 \%)$ meanwhile the majority of them illustrates a low level of linking social capital (46.70\%). For economic empowerment, the majority of them have a high level of economic empowerment (42.50\%). 
Table 3: Level of variables

\begin{tabular}{|c|c|c|c|c|}
\hline Variables & Frequency & Percentage (\%) & Mean & SD \\
\hline \multicolumn{5}{|l|}{ Participation } \\
\hline \multicolumn{5}{|l|}{ Planning } \\
\hline Low & 81 & $38.2 \%$ & \multirow{3}{*}{2.96} & \multirow{3}{*}{1.29} \\
\hline Moderate & 42 & $19.8 \%$ & & \\
\hline High & 89 & $42 \%$ & & \\
\hline \multicolumn{5}{|l|}{ Implementation } \\
\hline Low & 83 & $39.2 \%$ & \multirow{3}{*}{2.89} & \multirow{3}{*}{1.26} \\
\hline Moderate & 60 & $28.3 \%$ & & \\
\hline High & 69 & $32.5 \%$ & & \\
\hline \multicolumn{5}{|l|}{ Evaluation } \\
\hline Low & 91 & $42.9 \%$ & \multirow{3}{*}{2.93} & \multirow{3}{*}{1.31} \\
\hline Moderate & 42 & $19.8 \%$ & & \\
\hline High & 79 & $37.3 \%$ & & \\
\hline \multirow{2}{*}{\multicolumn{5}{|c|}{$\begin{array}{l}\text { Social Capital } \\
\text { Bonding }\end{array}$}} \\
\hline & & & & \\
\hline Low & 66 & $31.1 \%$ & \multirow{3}{*}{3.32} & \multirow{3}{*}{1.26} \\
\hline Moderate & 33 & $15.6 \%$ & & \\
\hline High & 113 & $53.3 \%$ & & \\
\hline \multicolumn{5}{|l|}{ Bridging } \\
\hline Low & 84 & $39.6 \%$ & \multirow{3}{*}{2.96} & \multirow{3}{*}{1.25} \\
\hline Moderate & 43 & $20.3 \%$ & & \\
\hline High & 85 & $40.1 \%$ & & \\
\hline \multicolumn{5}{|l|}{ Linking } \\
\hline Low & 99 & $46.7 \%$ & \multirow{3}{*}{2.79} & \multirow{3}{*}{1.16} \\
\hline Moderate & 43 & $20.3 \%$ & & \\
\hline High & 70 & $33 \%$ & & \\
\hline \multicolumn{5}{|c|}{ Economic Empowerment } \\
\hline Low & 61 & $28.8 \%$ & \multirow{3}{*}{3.16} & \multirow{3}{*}{1.11} \\
\hline Moderate & 61 & $28.8 \%$ & & \\
\hline High & 90 & $42.5 \%$ & & \\
\hline
\end{tabular}

\section{Multiple Linear Regression}

Multiple Linear Regressions were used in this study to predict the dependent variable (economic empowerment) from the set of independent variables (social capital and participation dimensions). As highlighted in Table 4, multiple linear regression analysis was applied using the "enter" method to evaluate the influence of social capital and participation variables towards empowerment of UA program's participants. The results showed that about $58,6 \%$ variance in economic empowerment was explained by all the predictor variables entered into the regression model. The regression equation predicting economic empowerment is: Economic Empowerment $=0.913+(0.156)$ Bonding $+(-0.018)$ Bridging + (0.637) Linking+ (0.275) Planning + (-0.074) Implementation $+(0.204)$ Evaluation. A significant regression was found between linking $(\beta=0.665, p<0.05)$, planning $(\beta=0.320, p<0.05)$, evaluation $(\beta=0.240, p<0.05)$ and economic empowerment of UA program's participants in the Klang Valley area. However, there is no significant difference between bonding $(\beta=0.177$, $p>0.05)$, bridging $(\beta=-0.020, p>0.05)$, bridging $(\beta=-0.084, p>0.05)$ and economic 
empowerment of UA program's participants. Depicting from the findings below, clearly social capital linking contributes the most to economic empowerment $(\beta=0.665)$, followed by planning $(\beta=0.320)$ and evaluation $(\beta=0.240)$.

Table 4: Factors Affecting Economic Empowerment

\begin{tabular}{lccccc}
\hline \multirow{2}{*}{ Model } & \multicolumn{2}{c}{$\begin{array}{c}\text { Unstandardized } \\
\text { Coefficient }\end{array}$} & $\begin{array}{c}\text { Standardized } \\
\text { coefficient }\end{array}$ & t & Sig. \\
\cline { 2 - 4 } & $\mathbf{B}$ & $\begin{array}{c}\text { Standard } \\
\text { Error }\end{array}$ & $\boldsymbol{\beta}$ & & \\
\hline (Constant) & 0.913 & 0.156 & & 5.838 & 0.000 \\
Bonding & 0.156 & 0.093 & 0.177 & 1.677 & 0.095 \\
Bridging & -0.018 & 0.094 & -0.020 & -0.188 & 0.851 \\
Linking & 0.637 & 0.089 & 0.665 & 7.187 & 0.000 \\
Planning & 0.275 & 0.090 & 0.320 & 3.055 & 0.003 \\
Implementation & -0.074 & 0.091 & -0.084 & -0.808 & 0.420 \\
Evaluation & 0.204 & 0.083 & 0.240 & 2.469 & 0.014 \\
\hline
\end{tabular}

Method $=$ Enter, $R=0.765, R 2=0.586$, Adjusted R2 $=0.574$

\section{Discussion and Conclusion}

Generally, based on this study's analysis, it can be concluded that the majority of the respondents are between the 41-60 years old age range. The result reflected that elders are more likely to participate in the program since most of them are retired and have a lot of time to engage with the community. Their expertise is often used and becomes a role model for youth to be involved in project activities, therefore, it is a good indicator for a government to play a part in attracting the elderly to participate in UA in the future. In accordance with Riwalnu (2014) study, which revealed that ages 40 and 52 are active in the community. Practically, they think more about how to develop a strong society with the current economic and social age.

In terms of gender, the result portrayed that the study population was dominated by males. This category indicates that these respondents were from the productive workforce of the Malaysian population and willing to spend their time participating in community activity. This is prior to research done by Nazuri and Ahmad (2019) that has shown that men are more interested and available to join urban farming programs. Besides, males received an opportunity to participate in a UA program. Besides, males are more socially active, play the role of the breadwinner, and are more aware of any issue (Othman et al., 2019). This study also revealed a large number of married couples (94.3\%) participate in this program since the neighborhood usually consists of family and married people. Findings from this study also noted that almost two-thirds of the respondents (62.3\%) attended secondary school/vocational school which showed that the majority of them have a moderate level of education.

The research sought to examine the contribution of social capital on the planning of an urban agriculture community in the Klang Valley, Malaysia. Apparently, this research has a significant contribution to society and academic purpose, as mentioned in the previous results, the key finding of this study is the existence of linking social capital resulting as the most potent mitigating factor of planning towards economic empowerment. Drawing on previous researchers, having social networks with outsiders (linking) allowed the community members to gain information, skill and participate in economic activities which will increase 
their income (Zal et al., 2013). The merit of a program can be achieved if the government and several private agencies (linking social capital) work hand in hand, cooperating with each other with the purpose for development of the program (Bebbington and Carroll, 2000). This is apprehensible for concern parties such as community developers and extension officers should give full cooperation towards strengthening the community's participation in the program. The officers should assist the community by providing programs such as workshops and farming management which promote active community participation. It also demonstrates that in endeavors to support UA activities in the Klang Valley area, communities need to be cognizant of issues of land availability for community garden development to increase the visibility of such practices in the community. Hence, with constant support and persistent programs by stakeholders and NGOs, it can drive the communities to manage and produce tangible results which may help to reinforce the commitment and participation of those involved and be more informed which, stakeholders will participate with their role, to promote transparency, building of trust and institutionalization of the process.

\section{References}

Abdul-Hakim, R., Abdul-Razak, N. A., \& Ismail, R. (2010). Does social capital reduce poverty? A case study of rural households in Terengganu, Malaysia. European journal of Social Sciences, 14(4), 556-566.

Asnarulkhadi, A. S., \& Aref, F. (2011). Theoretical Framework and Application of Community Empowerment and Participation in Process of Community Development in Malaysia. Journal of American Science, 7(2), 230-235.

Bebbington, A., \& Carroll, T. F. (2000). Induced social capital and federations of the rural poor. World Bank, Social Development Family, Environmentally and Socially Sustainable Development Network.

Bryson, B. S. (2018). Community mapping as a tool for developing culturally relevant pedagogy. The New Educator, 14(2), 109-128.

Burt, R. S. (2001). Closure as social capital. Social capital: Theory and research, 31- 55.

Claridge, T. (2018). Criticisms of social capital theory: And lessons for improving practice. Social Capital Research, 1-8.

Cohen, Nevin and Reynolds, Kristin (2015). Resource needs for a socially just and sustainable urban agriculture system: Lessons from New York City. Renewable Agriculture and Food Systems, 30(1), 103-114. doi:10.1017/S1742170514000210

Corrigan, M. P. (2011). Growing what you eat: Developing community gardens in Baltimore, Maryland. Applied Geography, 31(4), 1232-1241.

Department of Agriculture. (2019). Program Pertanian Bandar 2019. Retrieved from http://www.doa.gov.my/index.php/pages/view/332

Fielden, S. L., \& Hunt, C. M. (2011). Online coaching: An alternative source of social support for female entrepreneurs during venture creation. International Small Business Journal, 29(4), 345-359.

Geidam, A. A., Redzuan, M., \& Abu-Samah, A. (2012). Assessment of participation in afforestation programme and relationship to empowerment. International Journal of Academic Research in Business and Social Sciences, 2(8), 310.

Gittell, R., \& Vidal, A. (1998). Community organizing: Building social capital as a development strategy. Sage publications. 
Horst, M., McClintock, N., \& Hoey, L. (2017). The intersection of planning, urban agriculture, and food justice: A review of the literature. Journal of the American Planning Association, 83(3), 277-295.

Ibrahim, M. B. (2016). Role of participation in decision making and social capital on sustainability of watershed usage among peri-urban agricultural farmers of Kwadon, Gombe State, Nigeria (Doctoral dissertation, PhD thesis, Universiti Putra Malaysia.

Islam, R., \& Siwar, C. (2012). The analysis of urban agriculture development in Malaysia. Advances in Environmental Biology, 6(3), 1068-1078.

Kavanaugh, A., Carroll, J. M., Rosson, M. B., Zin, T. T., \& Reese, D. D. (2005). Community networks: Where offline communities meet online. Journal of Computer-Mediated Communication, 10(4), JCMC10417.

Laverack, G., \& Wallerstein, N. (2001). Measuring community empowerment: a fresh look at organizational domains. Health promotion international, 16(2), 179-185.

Lyndon, N., Moorthy, R., Er, A. C., \& Selvadurai, S. (2011). Native Understanding of Participation and Empowerment in Community Development. Journal of Social Sciences, 7(4), pp. 643-648.

Ndaeji, M. N. (2014). Participation in Self-help Groups and Empowerment among Rural Women in Niger State, Nigeria (Doctoral dissertation, Universiti Putra Malaysia).

Othman, N., Latip, R. A., \& Ariffin, M. H. (2019). Motivations for sustaining urban farming participation. International Journal of Agricultural Resources, Governance and Ecology, 15(1), 45-56.

Pelling, M., \& High, C. (2005). Understanding adaptation: what can social capital offer assessments of adaptive capacity? Global Environmental Change, 15(4), 308-319.

Poulsen, M. N., McNab, P. R., Clayton, M. L., \& Neff, R. A. (2015). A systematic review of urban agriculture and food security impacts in low-income countries. Food Policy, 55, 131-146.

Poulsen, S. E., Andersen, T. R., Thomsen, P., \& Havas, K. (2018). Geological characterization in urban areas based on geophysical mapping: a case study from Horsens, Denmark. Journal of Applied Geophysics, 150, 338-349.

Putnam, R. (1993). The prosperous community: Social capital and public life. The American Prospect, 13 (4).

Putnam, R. (2000). Social capital: Measurement and consequences. Canadian Journal of Policy Research, 2(1), 41-51.

Putnam, H. (2013). Meaning and the Moral Sciences (Routledge Revivals). Routledge.

Rezai, G., Shamsudin, M. N., \& Kit Teng, P. (2014). Public attitude toward urban agriculture in Malaysia: study on values and knowledge in Klang Valley. Journal of Food Products Marketing, 20, 35-48

Rilwanu, A. (2014). Participation, Social Capital and Empowerment among Members of Kankara Local Community Fadama User Groups in Katsina State, Nigeria (Doctoral dissertation, Universiti Putra Malaysia).

Siwar, C., Ahmed, F., Bashawir, A., \& Mia, M. S. (2016). Urbanization and urban poverty in Malaysia: consequences and vulnerability. Journal of Applied Sciences, 16(4), 154-160.

Sun, L., Chen, J., Li, Q., \& Huang, D. (2020). Dramatic uneven urbanization of large cities throughout the world in recent decades. Nature communications, 11(1), 1-9.

Tajuddin, Z., Sum, S. M., Zainol, R. M., \& Jusoh, H. (2019). Penentu Sosial Penglibatan Komuniti Dalam Projek Kebun Komuniti Bandar: Social Determinants of Community Involvement In Urban Community Garden Projects. SARJANA, 34(1), 56-68.

Tirmizi, S. N. A. (2005). The contribution of levels of social capital to community development. 
United Nation. (2014). World's population is increasingly urban with more than half living in urban areas. Retrieved from https://www.un.org/en/development/desa/news/population/world-urbanizationprospects-2014.html

United Nation. (2018). The Sustainable Development Goals Report 2018. Retrieved from https://www.un.org/development/desa/publications/the-sustainable-developmentgoals-report-2018.html

Wakefield, S. E., \& Poland, B. (2005). Family, friend or foe? Critical reflections on the relevance and role of social capital in health promotion and community development. Social Science \& Medicine, 60(12), 2819-2832.

Woolcock, M., \& Narayan, D. (2000). Social capital: Implications for development theory, research, and policy. The World Bank Research Observer, 15(2), 225-249.

World Urbanisation Prospects: https://population.un.org/wup/ 2019

Woolcock, M. (2001). The place of social capital in understanding social and economic outcomes. Canadian journal of policy research, 2(1), 11-17.

Tajuddin, Z., Sum, S. M., Zainol, R. M., \& Jusoh, H. (2019). Penentu Sosial Penglibatan Komuniti Dalam Projek Kebun Komuniti Bandar: Social Determinants of Community Involvement In Urban Community Garden Projects. SARJANA, 34(1), 56-68. 